\title{
MOS Gene
}

National Cancer Institute

\section{Source}

National Cancer Institute. MOS Gene. NCI Thesaurus. Code C16881.

This gene is involved in signal transduction and the control of meioses. 